УДК 316.4

\title{
Modern Nuclear Plant: Social Risks and Social Security from the Perspective of Post-non-classical Universum Sociology
}

\author{
Anna P. Kareeva* \\ Siberian Federal University \\ 79 Svobodny, Krasnoyarsk, 660041, Russia
}

Received 03.08.2015, received in revised form 16.09.2015, accepted 08.10.2015

The article presents an analysis of social risks with the use of the methodological principle of minimum universum. Social risks are divided between three levels: material-energetic, functional-organizational and informational. It is noted that at the present stage of development of society and social institutions social security has become their normative ideal. In the modern industrial enterprise, it aims to reduce the emerging social risks. The qualitative analysis of documents proved that the occurrence of a certain social risk depends on the historical period of development of the enterprise. A questionnaire survey using the factor and correlation analysis revealed social risks of the studied nuclear plant, their perception by the employees, as well as the role of industrial social security in addressing these risks.

Keywords: social risks, industrial plant, socialsecurity, qualitative analysis of documents, questionnaire method, indices and indicators of social security, methodological principle of minimum universum, factor and correlation analysis.

DOI: 10.17516/1997-1370-2015-8-11-2448-2457.

Research area: sociology.

Risks are an important feature of modern society. They occur constantly and affect a significant number of people and social institutions. They are characterized by globality, universality, irremovability, long-range activity, regularity of occurrence, are generated by the industrial field and are a social process. It is impossible to eliminate them from society while there are rapid social and technological changes. Also, the occurrence of risks is provoked by a man himself taking certain decisions in a choice situation. Refusing to make a decision, he provokes their occurrence anyway. According to the concept of "risk society" only security can minimize the arising risks (Beck, 2000).

A variety of risks in society gives rise to various forms of security. According to V.N. Kelas'ev (1999), Russia has addressed social security quite recently. Over a long historical period it was characterized by a lack of attention to a person. This article pays attention to social security of the industrial plant.

Today, social security is considered from different points of view: as a part of national

(C) Siberian Federal University. All rights reserved

* Corresponding author E-mail address: karenina3010@rambler.ru 
security (Koptseva, 2014), in the context of globalization (Koptseva, 2012), as security of population from a number of risks (social, economic, environmental, etc.) (Kuznetsov, 2007). It, as well as social risks, is an integral part of modern society and has an impact on people's lives and social institutions. Its zone of influence includes all aspects of society from economic to cultural. Social security is intended to "soften, smooth, and eliminate social ills that are common today for our communities" (Levashov, 2002). The guarantor of its implementation is social policy of the state.

As a social institution, an industrial plant is also experiencing the impact of social risks and social security. So under the influence of internal and external factors social risks occurs constantly there. In total, we were able to identify six groups of social risks, the occurrence of which is possible in the plant.

1. Downside risks to the economic wellbeing of an employee.

2. Downside risks to the personal security of employees.

3. Downside risks to the scientific-technical and technological potential of employees.

4. Medical risks.

5. Environmental risks.

6. Downside risks to the social stability of the plant.

In this regard, at the present stage of the social development no commercial enterprise can exist without social security.

The main task of industrial social security is to reduce industrial social risks arising thereon. It takes the company's one of the leading places penetrating all spheres of its life. The subject of social security is an employee of the plant. It makes the main demand on it - to reduce social tension and to make its working life relatively stable. If this demand is fulfilled, an employee of the plant accepts and supports its effectiveness.
For him, it is also important that social security is equally aimed at all employees, regardless of their professional status. Social security is implemented through social policies pursued by the plant. If social policy is fully or partially satisfies the needs of employees, then social security will be high and vice versa.

The definition we have given to the industrial social security is as follows: "Social security of a large industrial enterprise is an essential characteristic of a modern enterprise that permeates all aspects of its production life and is designed to protect the needs of all employees from social risks and social tension arising thereon."

Social security is manifested through the indicators that are based on the needs of employees of the plant.

1. Economic well-being.

2. Personal security.

3. Professional growth.

4. Industrial infrastructure.

5. Social stability.

6. Social and living infrastructure.

7. Creative initiative.

8. Participation of employees in production management.

The objects of our study are the social risks occurring on a large industrial plant, and the subject of the study is the perception of these risks by the plant's employees. The study was conducted at the Mining and Chemical Plant located in Zheleznogorsk, Krasnoyarsk Territory. The MCP is the largest nuclear plant employing more than 4500 people.

It has been hypothesized that the Mining and Chemical Plant like any industrial enterprise has been and still is facing social risks. At this, the employees' perception of these risks depends on the implementation of social security therein.

The research methods we used are a qualitative analysis of documents and a 
questionnaire survey. The form of the survey is a group survey.

For the qualitative analysis, we investigated the regulatory and administrative documents of the plant, annual reports, statistical references, provisions, development strategy, collective agreement, issues of the corporate newspaper from 1995 to 2009, videos and monographs published by members of the Mining and Chemical Plant, etc. There are about 50 documents.

The survey was held at the MCP from November to December 2013, with the participation of the author and volunteers. 1120 people were interviewed using the proportional stratified sampling. For the analysis of the results we used the program SPSS Statistics 20.0. In order to identify the pair correlations between the studied elements we used the Pearson correlation method, and for the factor analysis - the Varimax method.

Interpretation of the results was carried out from the perspective of a universum sociological paradigm (Nemirovskii, 1994). This paradigm includes all the main features of the post-nonclassical stage of development sociology. Based on the methodological principle of minimum universum, which is a matrix that is the basis for the process of development of the system, the principle of minimum universum consists of two elements, three levels, five states, seven layers and twelve qualities. At this, the universum approach has been successfully used for the analysis of social institutions and organizations, as well as of various social groups (Nemirovskii \& Nevirko, 2006), etc.

In this article, an undifferentiated protosystem is a large industrial plant. Two polar elements of the plant from the perspective of minimum universum are its social security and social danger (social risks). In the current situation, both elements are always present in every industrial enterprise. The ratio depends on its social policy, as well as on the perception of the enterprise's employees as socially secure or socially insecure.

According to the principle of minimum universum, every developing system forms three levels in the process of change: material-energetic, functional-organizational and informational. The social risks we allocated were divided between them.

The material-energetic level covers the downside risks to the economic well-being of an employee, personal security, health and environmental risks; the functionalorganizational level includes the downside risks to the social stability of the enterprise. The third, informational, level is presented by the downside risks to the scientific-technical and technological potential of employees. At each level, the needs of employees are realized or not realized. After all, the needs "are a "bridge" that connects a personality with its social environment" (Nemirovskii, 2003).

The analysis yielded the following results.

Employees of the plant noted that there were always social risks in the Mining and Chemical Plant throughout its existence, and their manifestation was conditioned by the historical periods of development of the enterprise. Through the qualitative analysis of documents, we identified the historical periods of development of the plant and their characteristic social risks. During formation of the plant (the $50 \mathrm{~s}$ ) all six groups of social risks that we have found were equally presented at the plant. In the heyday of the plant (the 60-80s), all social risks were minimized. During the crisis period of the MCP (the 90s), activities of the two groups of risks were the most actualized - downside risks to the economic well-being and social stability. At the present stage of the plant's development (since 2000) there are three most significant groups of social risks. These are the downside risks to 
the social stability of the plant, the downside risks to the economic well-being and personal security. The survey confirmed these findings. The allocated social risks concern both workers of the each plant separately (RP, RCP, ICP) and workers of the enterprise as a whole.

Let us note that the presence of social risks at the plant indicates the presence of social security and its indicators.

The factor analysis showed that three of the eightindicators of social security are "implemented insufficiently" at the Mining and Chemical Plant. This, in turn, creates difficulties in the perception of social security by its employees.

Let us consider each of the indicators in detail. For ease of analysis, each of them was divided into indicators. The qualitative analysis of documents is also allowed us to trace their formation in all historical periods of development of the enterprise.

The first indicator, "Economic wellbeing", includes two indicators, such as "material compensation of employees" and "social package of the enterprise". According to the factor analysis, only one indicator ("material compensation of employees") is implemented insufficiently at the plant (Pearson's correlation coefficient of 0.5).

$89 \%$ of respondents, regardless of gender, age and position, consider this indicator to be "important" for the economic well-being of employees.

The first significant problems in the wage system occurred at the plant in the crisis period of development (the 90s). Wages were paid irregularly, their growth lagged behind the price of the consumer basket. Allowances paid to employees for outstanding achievements were personalized and one-time only; their issue was due to the anniversaries of the employees and did not cover the rapid growth of inflation. Shifts in wages of employees have emerged only at the present stage of development of the enterprise. Since 2006, salaries have significantly increased at the plant, indexation of salaries of employees has been carried out in accordance with the annual rate of inflation, and a new unified wage system has been introduced. The introduction of the unified wage system allowed for adjustments in staff salaries in the nuclear power industry, in case it was lagging behind the market average.

However, despite the changes that have occurred in the wage system, this indicator, according to the staff, is still "poorly implemented" in the enterprise. The workers of the isotope-chemical plant (78 \%) and the reactor plant (74\%) are least satisfied with their salary. They believe that they earn less than the workers from other units of the MCP, although the work load is larger, more important and urgent.

The employees of all plants say that the lack of decent material remuneration makes them think about changing jobs. To date, about a third of the employees of each of the plants (RP $28 \%$, RCP - $22 \%$, ICP - $32 \%$ ) would like to move to another unit of the plant for the same

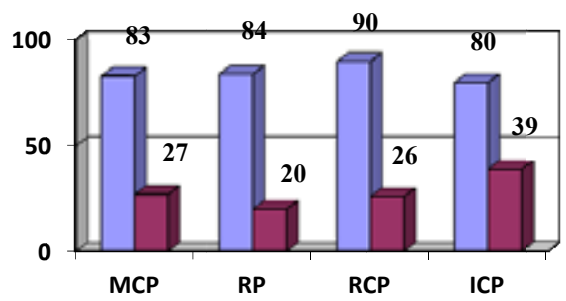

$\square$ important indicator of social security

$\square$ realized indicator of social security

Fig. 1. Availability of conditions for the employee's high-quality performance of work (\%) 
or a more payable position. A large percentage of those wishing to change their workplace are among the young employees of the enterprise (age of up to 35 years). Only $26 \%$ of them want to remain in their workplace, and the rest are ready to change it. Some want to move to another unit of the MCP (33\%), others are ready to apply for a new enterprise with the same working conditions $(11 \%)$ or better working conditions ( $24 \%)$.

The second indicator, "Personal Safety", includes four indicators, such as "conditions for the employee's high-quality work", "safety measures", "employee's understanding of production problems" and "employee's understanding of the results of their work, their importance for the plant".

At the heart of the emergence of this group of risks there are difficulties with the introduction of the scientific organization of labour at the enterprise. The more problems with the introduction of the scientific organization of labour, the more risks occur. The qualitative analysis of the documents revealed that the greatest difficulties with the introduction of the scientific organization of labour were experienced by the plant in the period of its formation (the 50s). After all, in addition to the basic elements of the scientific organization of labour at the plant, there should have been specific elements as well. The presence of specific elements was due to the peculiarities of the technological process of the nuclear enterprise. Their introduction took place

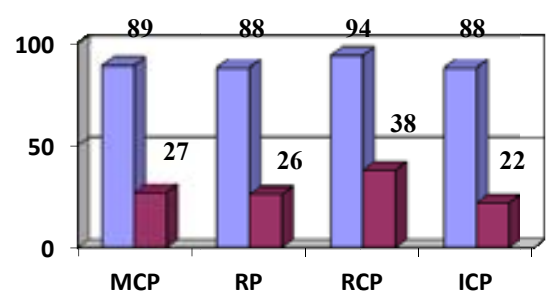

gradually and was intended to protect employees from harmful effects of the technological process.

Today, the importance of the scientific organization of labour for the employees is due to the fact that the new production facilities are being built in the territory of the plant, and the scope of production tasks for the enterprise unites are growing. According to the employees of the plant, the scope of production tasks in the last year has increased by several times. Thus, the growth was $40 \%$ at the ICP and the RP and $50 \%$ - at the RCP. In this regard, certain questions arise, such as those related to the organization of material and technical supply of the units, equipment of the workers with quality tools, creation of conditions for the employees' high-quality performance of their tasks. It becomes important for the workers to understand their production tasks, the results of their work, their significance for the activity of the entire plant.

According to the factor analysis, out of the four indicators only one ("availability of conditions for the employee's high-quality performance of work") is implemented insufficiently at the plant (Pearson's correlation coefficient of 0.7).

The employees consider this indicator to be "important", but "difficult to realize".

According to the respondents, to date, the MCP employee is not provided with all the necessary equipment and tools, as well as with conditions for high-quality performance. It is noted by $83 \%$ of respondents.

Fig. 2. Material compensation of employees (\%)

$\square$ important indicator of social security

$\square$ realized indicator of social security 
They believe that part of the equipment, machinery, aggregates and tools require substantial renovation. Workplaces of both specialists and workers require qualitative modernization as well. $65 \%$ of workers and $50 \%$ of specialists of the plant spoke about that need. The problem of modernization of workplaces is quite acute among the workers at the RCP, as well as among the specialists and workers of the RP. For specialists it is important to equip workplaces with modern computers and software, office equipment, furniture and stationery. For the workers, the most important is to comply with the sanitary and hygienic conditions in the workplace (lighting, noise level, dustiness, lack of harmful particles and so on), to equip it with modern furniture, machine tools, to timely deliver high-quality consumables for work, to timely and sufficiently equip the workplace with different and qualitative tools and work wear. The organization of the working process also requires modernization.

The third indicator, "Social stability", includes six indicators, three of which, according to the factor analysis, are insufficiently implemented at the MCP. These are the employee's confidence in the future (Pearson's correlation coefficient of 0.6 ), recognition of the employee's distinguished work (Pearson's correlation coefficient of 0.6), timely material and moral encouragement of the employee from the enterprise's management (Pearson's correlation coefficient of 0.7).

The downside risks to the social stability are broad and cover various areas of working life of staff from the interaction within the working team to the social sphere. Disorder in at least one of them destabilizes the working life of the employee. The qualitative analysis of documents allows us to say that this group of risks was always present at the Mining and Chemical Plant. Various aspects of life of staff caught its attention in different historical periods.
Thus, in the formation period of the enterprise (the 50s) a risk associated with low levels of social sphere comes to the fore. The social sphere of that period can be characterized as follows: lack of good roads, dirt, wooden barracks, minimum conveniences, poor heating, large-scale construction works. At the same time, the enterprise employees have a sense of stability and confidence in the future. The plant under construction has goals, objectives and prospects.

In the heyday of the enterprise (the 60-80s) there was improvement in the social sphere of employees. Significant changes affected living conditions. Simultaneously with the construction of housing, cultural and social facilities were built, leisure activities of the plant workers improved. Changes in the social sphere brought positive results to the plant. Thanks to that, staff turnover reduced significantly. By the $80 \mathrm{~s}$, labour dynasties occurred at the plant. Stability and confidence in the future of the employee in the $60-80$ s were at a high level. The enterprise had prospects, the working team expanded, new production facilities were being built, and the latest technologies were being introduced.

In the 90 s, the downside risks to the social stability of employees get aggravated. During this period, the employees' confidence in the future is getting reduced, a sense of stability is decreasing, and social conditions are deteriorating. The plant management is taking measures to address emerging problems. For example, the reduction of personnel is carried out using natural attrition (retirement), as well as by reducing the recruitment of professionals, including the youth. To solve the housing problem, the plant is beginning to attract workers' funds for the completion of houses and leave apartments for self-finishing. For the first time it is possible to buy out an apartment.

The modern period (2000) reduces the risks aggravated in the 90s. Today, however, the plant 
employees continue to face insecurity in the future, feel that they get insufficient recognition of their labour achievements and do not receive timely material and moral encouragement of their labour from the plant's management.

The indicator "employee's confidence in the future" is considered to be "important" by $83 \%$ of employees at the Mining and Chemical Plant. The respondents note that confidence in the future gives an employee a sense of stability.

According to the surveyed young employees of the enterprise, it is confidence in the future that is the main reason of their employment at the Mining and Chemical Plant. $54 \%$ of young employees say the same. However, they point out that in the course of work their confidence has declined. As a result of several years of work, young employees noted that $43 \%$ of them began to feel insufficient confidence in their future.

The following indicators of the factor "Social stability", such as "recognition of the employee's achievements of work from management" and "timely material and moral encouragement

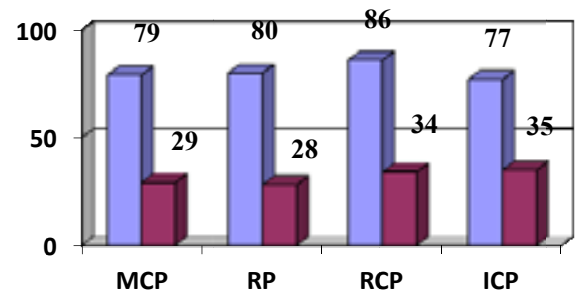

Fig. 3. Employee's confidence in the future (\%) of employees from the plant's management (bonuses)" are considered to be "important" by $80 \%$ of respondents.

However, Figure 4 shows that the recognition of the employee's labour achievements in all its importance is poorly implemented at the plant. The respondents note that over the last year the value of an ordinary employee rose insignificantly: at the ICP - by $3 \%$, at the RP and the RCP - by $12 \%$. The employees of the plant believe that selection of candidates for awarding is insufficiently objective, without clear and understandable criteria for selection.

The results of sociological studies show that this indicator mostly concerns young specialists of the plant (91\%) and workers of units (ICP $57 \%, \mathrm{RCP}-52 \%, \mathrm{RP}-41 \%$ ). It is unequally realized in the units of the plant. Thus, material and moral encouragement of employees at the $\mathrm{RP}$ and RCP is implemented better than at the ICP. Only $20 \%$ of employees at the ICP note that the results of their work receive timely assessment by the management, the remaining $80 \%$ - do not. The category of underrated staff at the Isotope-

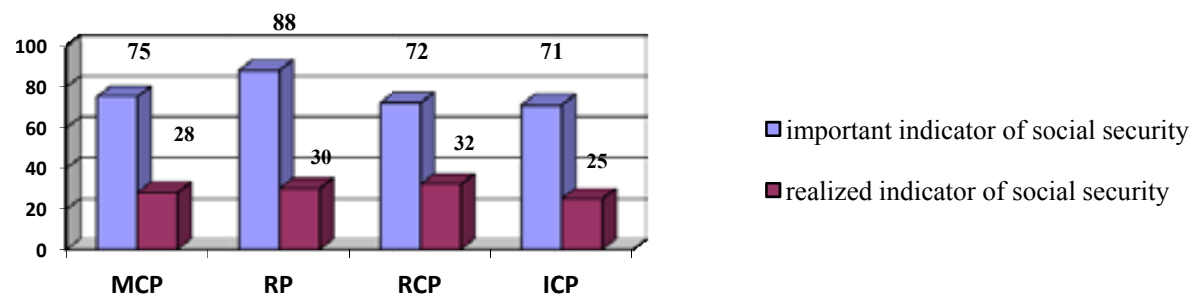

Fig. 4. Recognition of the employee's achievements of work from management (\%) 


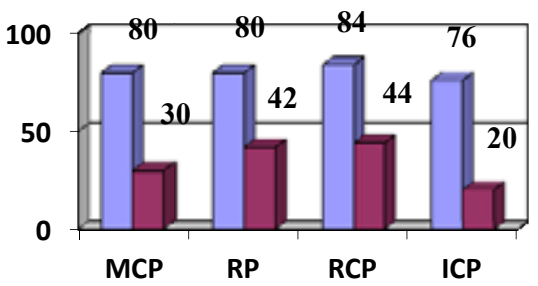

口important indicator of social security

口realized indicator of social security

Fig. 5. Timely material and moral encouragement of employees from the plant's management (bonuses) (\%)

Chemical Plant included not only workers, but also specialists and middle managers.

Three indicators that are "insufficiently implemented" at the Mining and Chemical Plant were assigned by us to the material-energetic and functional-organizational levels of the principle of minimum universum. The material-energetic level includes two of the three "insufficiently implemented" indicators of social security, and the functional-organizational level includes one indicator. These levels are risk-taking for the plant. Let us note that the risks of the material-energetic level have a direct impact on the occurrence of the risks of the functional-organizational level. So the lack of financial reward of the employees reduces their confidence in the future. Poor conditions for high-quality performance of work of the staff do not allow most of them to express themselves in the work properly. This leads to underestimation of employees from management, to weak recognition of their labour achievements, to a lack of material and moral encouragement for their work.

In conclusion, it should be noted that like any modern industrial enterprise the Mining and Chemical Plant is risk-taking. It covers various risks, including social risks. They cover all aspects of life of the enterprise, and their occurrence depends on the historical periods of its development. Minimization of the consequences of risks for the personnel is carried out by the industrial social security formed at the plant. To date, not all indicators of social security of the MCP are implemented in full. In this regard, we can conclude that the current social security at the Mining and Chemical Plant cannot completely eliminate all social risks existing there.

\section{References}

Beck, U. Obshchestvo riska. Na puti k drugomu modern [Risk Society. Towards a new modernity]. Moscow, Progress-Traditsiia, 2000, pp. 9-146.

Kelas'ev, V.N. (1999). Sotsial'naia zashchita naseleniia i vlast' [Social protection of population and power]. Journal of Sociology and Social Anthropology, 2(2), pp.80-89.

Koptseva, N.P. (2014). $K$ voprosu o kontseptual'nykh osnovaniiakh stroitel'stva obshchenatsional'nogo rossiiskogo gosudarstva. [On the question of conceptual foundations of the national construction of the Russian state] Problemy politiki i obshchestva [Issues of politics and society], 2014, 1. pp.1-14.

Koptseva, N.P. (2012). Kul'turologicheskaia baza formirovaniia obshchenatsional'noi rossiiskoi identichnosti v sibirskikh regionakh Rossiiskoi Federatsii [The cultural base of the formation of national identity in the Siberian regions of the Russian Federation]. Journal of Volgograd State University. Philosophy, 3(18), pp. 11-15. 
Kuznetsov, V.N. Sotsiologiia bezopasnosti [Sociology of security]. Tutorial. Moscow, 2007, $423 \mathrm{p}$.

Levashov, V.K. (2002). Globalizatsiia i ustoichivoe razvitie. Ustoichivoe razvitie [Globalization and Sustainable Development. Sustainable development]. Science and Practice, 1, pp.19-38.

Nemirovskii, V.G. Osnovy teoreticheskoi sotsiologii [Fundamentals of theoretical sociology]. Krasnoyarsk State University Publishing House, 1994, 133 p.

Nemirovskii, V.G. \& Nevirko, D.D. Sotsiologiia cheloveka: ot klassicheskikh kpostneklassicheskim podkhodam [Sociology of a person: from classical to post-non-classical approaches]. Krasnoyarsk, Siberian Law Institute of the Ministry of the Interior of the Russian Federation, 2006, 396 p.

Nemirovskii, V.G. Sovremennaia teoreticheskaia sotsiologiia [Modern theoretical sociology]. Krasnoyarsk State University Publishing House, 2003, 303 p.

Nemirovskii, V.G. Tainye obshchestva i zagovorshchiki: kuda oni vedut Rossiiu? [Secret societies and conspirators: where do they lead Russia?] St. Petersburg, 2007, 240 pp.

Nemirovskii, V.G., Starikov, P.A. (2003). Tendentsiia kvazireligioznosti v srede krasnoiarskogo studenchestva [Quasi-religious trend among Krasnoyarsk students]. Sociological Studies, 2003, 10, pp. 96-100.

Nemirovskii, V.G. Vvedenie $v$ teoreticheskuiu sotsiologiiu. Universumnaia paradigma [Introduction to theoretical sociology. Universum paradigm]. Krasnoyarsk State University Publishing House, 1991, 122 p.

Yanovskii, R.G. Global'nye izmeneniia i sotsial'naia bezopasnost' [Global changes and social security]. Moscow, Academia, 1999, p. 39.

Zerkalov, D.V. Sotsial'naia bezopasnost' [Social Security]. Kiev, Osnova, 2012, 530 p. 


\title{
Современное атомное предприятие:
}

\section{социальные риски и социальная безопасность \\ с позиции постнеклассической универсумной социологии}

\author{
А. П. Кареева \\ Сибирский федеральный университет \\ Россия, 660041, Красноярск, пр. Свободный, 79
}

\begin{abstract}
В статье представлен анализ социальных рисков с использованием методологического принцииа минимального универсума. Социальные риски разделены между тремя уровнями: веществвенноэнергетическим, функционально-организационным и информационным. Отмечается, что на современном этапе развития общества и социальных институтов сочиальная безопасность стала их нормативным идеалом. На современном промышленном предприятии она направлена на снижение возникающих сочиильных рисков. С помощью качественного анализа документов доказано, что возникновение того или иного социального риска зависит от исторического периода развития предприятия. Проведенный анкетный опрос с использованием факторного и корреляционного анализа позволил выляить сочиальные риски изучаемого атомного предприятия, их восприятие сотрудниками, а также роль промышленной социальной безопасности в решении данных рисков.

Ключевые слова: сочиальные риски, промышленное предприятие, сочиальная безопасность, качественный анализ документов, метод анкетного опроса, показатели и индикаторы социальной безопасности, методологический принцип минимального универсума, факторный и корреляиионный анализ.
\end{abstract}

Научная спещиальность: 22.00.00 - сочиологические науки. 